\title{
Special issue on international migration: editorial introduction
}

\author{
Masood Gheasi · Peter Nijkamp • Jacques Poot
}

Published online: 2 September 2012

(C) Springer-Verlag 2012

Migration has long been a core topic in regional science, as early reviews such as Greenwood (1985) demonstrate. Most attention to date has been devoted to causes and consequences of interregional migration, not only because of the availability of data but also because of the internal distribution of population being a major concern of policymakers. Since the 1980s, however, attention has shifted to international migration due to the tremendous growth in the number of foreign-born migrants in most developed countries. For quite some time, this trend was not picked up in the regional science literature (but see, e.g., Poot 1996 for an early contribution). However, in recent years, a growing number of papers at regional science meetings have been devoted to patterns of international migration and their impacts. The fruits of this endeavor are now emerging in the literature - as recent articles in the Annals indicate (Ekberg et al. 2010; Clemente et al. 2011; Van der Vlist et al. 2011; Sahin et al. 2011).

Many questions remain regarding the determinants of patterns of international migration, the consequences for sending and host countries, and the integration of immigrants in host societies. Consequently, some special sessions were devoted specifically to these issues at the 50th congress of the European Regional Science Association in Jönköping, Sweden during August 2010. Following a rigorous refereeing process,

\footnotetext{
M. Gheasi (凶) · P. Nijkamp

Department of Spatial Economics, VU University, De Boelelaan 1105, 1081 HV Amsterdam, The Netherlands

e-mail: m.a.g.gheasi@vu.nl

P. Nijkamp

e-mail: p.nijkamp@vu.nl

J. Poot

National Institute of Demographic and Economic Analysis, University of Waikato, Private Bag 3105, Hamilton, New Zealand e-mail: jpoot@waikato.ac.nz
} 
five of the papers presented at that conference constitute this (mini) special issue. The papers each offer quite different, but complementing, perspectives on international migration. Before outlining and integrating the contributions of these papers in this editorial introduction, we first offer some general remarks that set the scene.

Throughout human history, migration has been a courageous expression of the individual's will to overcome adversity and to live a better life. Push factors (such as poverty, a lack of employment opportunities, conflict, and natural disasters) and pull factors (such as higher employment, more wealth, social cohesion, good climate, political stability, and a low risk of natural hazards) made millions of people to move from their country of origin to other countries and even to different continents. The global number of international migrants is estimated to have increased from 80 million in 1970 to 214 million in 2010 (of whom $7 \%$ were refugees). This is equivalent to $2.2 \%$ of the world population in 1970 and $3.1 \%$ in 2010 . Of course, the majority of migrants end up in the developed countries, with immigrants being more than $12 \%$ of the population in OECD countries.

Globalization has led to intensifying cross-border networks and linkages. The expansion of global transport infrastructure, competitive forces, and transportation technology have made in particular air travel cheaper than ever before. Moreover, cheap international communication lowers the cost of migrants maintaining relationship capital (McCann et al. 2010). These trends have together led to a remarkable increase in short-range and long-range mobility of people that has contributed to greater international migration, with immigrants conventionally defined as anyone living 12 months or more outside their country of birth. Consequently, cross-border migration has become a mega-trend of a globalizing world, to the extent that some people even speak of the 'age of migration' (see Goldin et al. 2011).

What determines the spatial patterns of international migration? To answer this question, A. Caragliu, C. Del Bo, H. L. F. de Groot, and G.-J. M. Linders use the conventional but remarkably robust workhorse of spatial interaction modeling: the gravity model, which has been applied to international bilateral flows since Tinbergen (1962) and Pöyhönen (1963), who were the first to model international trade patterns. Various microfoundations have now been given for why the Newtonian law of physics (which states that the gravitational attraction exerted on an object by a body declines with the (squared) distance between the objects attracted and is proportional to the masses of the bodies) is a consistent empirical success in explaining different types of flows, such as migration, commuting, shopping trips, tourism, and trade (see also Genc et al. 2011).

Caragliu et al. use predominantly EUROSTAT data on flows between global source countries and European destinations. Caragliu et al. find that international migration is positively related to the population "mass" of the origin and destination countries, while inversely related to the distance between capital cities. The elasticities are much lower, however, than those suggested by the physical gravity model (which are 1, 1 and -2 respectively). Caragliu et al. argue that what matters more than physical distance is the cultural distance between the countries. They measure this cultural distance in various ways, through inter-country differences in trust, financial transparency, materialism, secularization, and democracy. The authors conduct a wide range of robustness checks of their model and find broad support for the hypothesis that not only 
geographical distance but also cultural distances in terms of differences in trust, finance, and institutions exert a negative effect on migration flows. However, the magnitude of the impact of cultural distance is rather sensitive to the specifications. Moreover, the underlying behavioral mechanisms warrant further attention, ideally by means of micro data.

In the second paper of this mini special issue, A. Ivlevs focuses on the propensity to emigrate from the perspective of one of the more recent EU member states, namely Latvia. Using 2005 survey data, he models emigration intentions by means of an ordered probit model. The case of Latvia is of interest because of the large inward migration of ethnic Russians, Byelorussians, and Ukrainians up to the 1980s and the radically changing status of these immigrants in the host society following the break-up of the Soviet Union in 1991. Since then, Russian is no longer recognized as an official language, which puts the migrants, who are often monolingual, at an economic disadvantage. Nonetheless, following an initial wave of return migration, many ethnic Russians remained, among whom a significant number had been born in Latvia. Ivlevs shows that once Latvia entered the EU, the Russian speaking minority were more likely to want to emigrate than the Latvian speakers. Moreover, those having higher education levels had a higher probability of emigration. A lack of data make it impossible to accurately assess to what extent the 2005 migration intentions led to subsequent outflows, but the modeling suggested the potential of a brain drain that could be detrimental to economic development of Latvia. The findings are likely to apply to several other Central and Eastern European countries as well.

Ethnicity and migrant networks are not only factors in emigrant self-selection, but they also impact on integration of immigrants in the host country. K. M. Mane and B. S. Waldorf consider two countries which are geographically similar in terms of their location on the globe and distance from the US, but which have had very different migration histories in terms of the volume and timing of inflows into the latter country. The two migrant source concerned are Albania, which is a recent source of migrants to the US, and Italy, which has been a source of US immigrants since the late 19th century. Mane and Waldorf conduct a microdata analysis based on a sample of 1,151 Albanian-born and 3,432 Italian-born residents of the US, merging data from the 2000 census and post-2000 American Community Surveys. Mane and Waldorf estimate Mincerian earnings equations and find that there is significant heterogeneity across the two migrant groups. This heterogeneity is partly due to selection effects: new immigrants from Italy include professionals whose migration to the US is only intended to be temporarily. Predictors include human capital, immigration-specific variables such as age at entry and English language proficiency, conventional earnings determinants such as demographic characteristics and occupation, and location in the US. Controlling for all these factors, Albanian immigrants earn less than their Italian counterparts. It is posited that this earnings gap is predominantly determined by the lesser transferability of Albanian educational credentials and experience. Nonetheless, the increase in earnings after settlement in the US is faster for this group which starts with the greater initial income gap, a finding which is quite common in the literature on immigrant economic assimilation.

International migration is not a stand-alone process, but interrelated with other international flows such as trade, foreign direct investment (FDI), tourism, and 
remittances. For example, the ratio of global merchandise exports to global GDP increased from under $11 \%$ in 1970 to over $26 \%$ by 2008 (World Bank 2010). FDI has similarly increased from 7 to $22 \%$ of global GDP between 1980 and 2003 (Wickramasekara 2008), and the growth in tourism was even stronger with 700 million worldwide tourist trips in 2000 as compared to 25 million in 1950 (Fischer 2007). Finally, remittances into the developing world increased fivefold between 1990 and 2004 (World Bank 2008).

Migrants are considered a bridge of information between the host country and their country of origin. Moreover, they boost an interest in the range of goods, services, and amenities on offer in the host and home countries. Consequently, studies have found a close relationship between immigration and international trade (reviewed by Genc et al. 2011), and between immigration and international tourism (reviewed by Gheasi et al. 2011). In this special issue, M. Gheasi, P. Nijkamp, and P. Rietveld consider the link between migration and FDI. Gheasi et al. focus on inward and outward FDI with respect to the United Kingdom, using annual data from 2001 to 2007. The approach is again a gravity model. They find that generally outward FDI from the UK, but not inward FDI into the UK, is affected by the stock of migrants from the destination and source countries, respectively. However, knowledge migrants (those with higher education) have a positive association with both inward and outward FDI, while immigrants with lower education are negatively correlated with both inward and outward FDI. Of course, in these kinds of models, there is likely to be reverse causation: FDI may trigger migration. Gheasi et al. control for this by an instrumental variables approach in which the 10 years lag of the share of UK migrants on origin country population, the cost of passports and religion (a dummy variable for Islamic countries) are valid instruments. The results are robust to the IV approach.

The final paper in this special issue, by J. Dzansi, focuses on another type of financial flows triggered by international migration, namely remittances. Dzansi notes that total global remittances amounted to US $\$ 161$ by 2004 , a substantial source of income for developing countries. The literature is divided about whether these remittances are beneficial or harmful for the recipient countries. The inflow of funds could increase the real exchange rate, which in turn may reduce the export growth potential of the developing country. Moreover, remittances are a source of non-wage income for the households left behind by the migrants: this could reduce labor supply. Opposite the negative effects are the possibilities that remittances could provide finance for investment and that they would certainly boost consumption, with potential multiplier effects. Dzansi finds by means of panel regression modeling that there is on balance a positive impact of remittance inflows on manufacturing growth. This effect is qualitatively robust to variations in specification and accounting for endogeneity by means of 2SLS, although the magnitude of the effects depends rather strongly on the selected model.

In summary, this special issue provides a range of perspectives on econometric modeling of causes and consequences of international migration. Although the volume of global migration has dampened somewhat in recent years due to the global financial crisis (e.g., Castles 2011), the likely further intensifying economic interaction between the countries of the world and the increasing geographic mobility of people suggests that international migration will take an even more prominent place in global socio 
economic transformation in the future. We may expect therefore a healthy growth in research activity on this topic by regional scientists.

Acknowledgments The papers in this special issue were first presented at the 50th Congress of the European Regional Science Association in Jönköping, Sweden, August 19-23, 2010. The sessions were organized under the auspices of the Migrant Diversity and Regional Disparity in Europe (MID-REDIE) research project, funded by the Norface research programme on migration, http://www.norface-migration. org/. We acknowledge the assistance of Ceren Ozgen in organizing the conference sessions on international migration.

\section{References}

Castles S (2011) Migration, crisis, and the global labour market. Globalizations 8(3):311-324

Clemente J, Gonzalez-Val R, Olloqui I (2011) Zipf's and Gibrat's laws for migration. Ann Reg Sci 47: 235-248

Ekberg J, Hammarstedt M, Shukur G (2010) Immigrant-native earnings differentials: SUR estimation applied on three generations. Ann Reg Sci 45:705-720

Fischer C (2007) The influence of immigration and international tourism on the import demand for consumer goods - theoretical model. In: Álvaro D, Nijkamp P, Neto P (eds) Advances in modern tourism research: economic perspectives. Physica-Verlag, Heidelberg, pp 37-49

Genc M, Gheasi M, Nijkamp P, Poot J (2011) The impact of immigration on international trade: a metaanalysis. Norface discussion paper 2011/20. http://www.norface-migration.org

Gheasi M, Nijkamp P, Rietveld P (2011) Migration and tourist flows. In: Matias A, Nijkamp P (eds) Advances in tourism economics. Physika-Verlag, Heidelberg, pp 111-126

Goldin I, Cameron G, Balarajan M (2011) Exceptional people. Princeton University Press, Princeton

Greenwood MJ (1985) Human migration: theory, models and empirical studies. J Reg Sci 25(4):521-544

McCann P, Poot J, Sanderson L (2010) Migration, relationship capital and international travel: theory and evidence. J Econom Geogr 10(3):361-387

Poot J (1996) Information, communication and networks in international migration systems. Ann Reg Sci 30(1):55-73

Pöyhönen P (1963) A tentative model for the volume of trade between countries. Weltwirtschaftliches Archiv 90:93-99

Sahin M, Nijkamp P, Stough R (2011) Impact of urban conditions on firm performance of migrant entrepreneurs: a comparative Dutch-US study. Ann Reg Sci 46:661-689

Tinbergen J (1962) Shaping the world economy: suggestions for an international economic policy. The Twentieth Century Fund, New York

Van der Vlist AJ, Czamanski D, Folmer H (2011) Immigration and urban housing dynamics: the case of Haifa. Ann Reg Sci 47:585-598

Wickramasekara P (2008) Globalisation, international labour migration and the rights of migrant workers. Third World Q 29:1247-1264

World Bank (2008) World development indicators. World Bank, Washington, DC

World Bank (2010) World development indicators. World Bank, Washington, DC 